\title{
Innovative Caciocavallo cheeses made from a mixture of cow milk with ewe or goat milk
}

\author{
Serena Niro, ${ }^{*}$ Alessandra Fratianni, ${ }^{* 1}$ Patrizio Tremonte, ${ }^{\star}$ Elena Sorrentino, ${ }^{\star}$ Luca Tipaldi, ${ }^{*}$ \\ Gianfranco Panfili, ${ }^{\star}$ and Raffaele Coppola* $\dagger$ \\ *Dipartimento Agricoltura, Ambiente e Alimenti (DiAAA), Università degli Studi del Molise, Via de Sanctis, 86100 Campobasso, Italy \\ †Istituto di Scienze dell'Alimentazione-CNR, Via Roma, 52 A/C, 83100 Avellino, Italy
}

\begin{abstract}
This study assessed and compared the physicochemical, microbiological, and sensorial characteristics of Caciocavallo cheeses, made from cow milk and a mixture of cow with ewe or goat milk, during ripening. Different cheese-making trials were carried out on an industrial scale following the standard procedure of pasta filata cheeses, with some modifications. The percentage of the different added milk to cow milk influenced compositional and nutritional characteristics of the innovative products, leading to a satisfactory microbiological and sensorial quality.
\end{abstract}

Key words: Caciocavallo cheese, ewe cheese, goat cheese, pasta filata cheese

\section{INTRODUCTION}

Pasta filata cheeses are typical Italian cheeses characterized by a unique technology because the curd, acidified and kneaded in hot water, produces the plastic consistency characteristic of these types of cheese. The Italian pasta filata cheeses include soft and semi-soft varieties consumed fresh or after a brief period of aging, and semi-hard or hard varieties that are subjected to considerable ripening before consumption (Coppola et al., 2003). One of the most important pasta filata cheeses in the Molise Italian Region is Caciocavallo. It is usually produced from cow milk, has a pear-like shape, and the head is closed by strings. It has an amber color, a homogeneous body with very few eyes, and 1 to $2 \mathrm{~kg}$ of weight. Some Caciocavallo cheeses are allowed to ripen for $15 \mathrm{~d}$ to $2 \mathrm{mo}$, some others, typical of southern Italy, can be ripened for longer periods such as $6 \mathrm{mo}$ or $1 \mathrm{yr}$. It is also consumed fresh and as an ingredient of typical traditional recipes.

Traditionally, Caciocavallo cheese is produced from raw milk without the addition of a starter culture even

Received October 1, 2013.

Accepted November 28, 2013.

${ }^{1}$ Corresponding author: fratianni@unimol.it if, during the last 2 decades, the use of pasteurized milk and starter cultures has been introduced into commercial practice to standardize cheese quality. Different types of Caciocavallo cheeses can be produced with different manufacturing technologies, varying the kind of milk used and its thermal treatment, the use of starter culture and its composition, and the curd and cheese ripening conditions (Niro et al., 2012), leading to products characterized by different traits. With regard to milk, different types of milk can be used, such as buffalo milk, as buffalo is part of the historic cultural heritage of South Italy. The cheese-making process of pasta filata cheese made from cow milk mixed with buffalo milk (Hussain et al., 2011) and from buffalo milk alone (Zicarelli, 2004) has been widely studied, together with the ripening step. Little research has been reported on the study of the processing parameters and on the characterization of pasta filata cheeses made from ewe and goat milk, alone or added to cow milk (Moatsou et al., 2001; Imm et al., 2003; Alichanidis and Polychroniadou, 2008; Albenzio et al., 2013), due to the poorer cheese-making ability of these types of milk compared with cow milk, which makes the stretching procedure difficult. Regarding cow/ewe and cow/goat pasta filata cheeses, little production is found in $\mathrm{Eu}-$ rope, depending on milk composition, which influences technology and yield. The most diffused is Kashkaval cheese, typical of Eastern Europe, Israel, and Turkey, which is simply called Kashkaval or Kashar (Albania), Kasar (Turkey), or Kasseri (Greece; Moatsou et al., 2001; Kindstedt et al., 2004; Alichanidis and Polychroniadou 2008; Litopoulou-Tzanetaki and Tzanetakis, 2011) and Metsovone, a semi-hard cheese produced in Greece. The 2 Italian products are Cofanetto, a typical Sicilian pasta filata cheese, made from a mixture of cow (70-80\%) and ewe milk (20-30\%) and Vastedda, entirely manufactured from ewe milk (Mucchetti et al., 2008).

The popularity of dairy products made from milk of small ruminants is increasing among researchers and the dairy industry, due to their peculiar taste 
and nutritional proprieties. Compositional differences between ewe milk and cow milk, mainly in proteins and fats, account for the different technological and sensorial characteristics of cheeses. Ewe milk contains higher protein and fat levels than cow milk (Kindstedt et al., 2004). Moreover, it is characteristic for the presence of small fat globules with an easily oxidizable weaker membrane. The lipids contain a higher percentage of short-chain FA, such as caproic, caprylic, and capric acids, which give a typical flavor characteristic (Park, 2001). Lipolysis in ewe cheeses is faster than in cow cheeses, contributing to an important flavor development (Park et al., 2007). Renneting parameters in cheese making from ewe milk are affected by its physicochemical properties, including $\mathrm{pH}$, larger casein micelles, more calcium per casein weight, and mineral contents in milk, which cause differences in coagulation time, coagulation rate, curd firmness, and amount of rennet needed (Park et al., 2007).

Goats produce only approximately $2 \%$ of the world total annual milk supply. Goat milk differs from cow milk from its higher digestibility, alkalinity, buffering capacity, and certain nutritional and therapeutic properties (Park, 2000). The composition of goat milk is similar to cow milk, although it has a smaller fat globular size and a whiter color than cow milk, as goats convert all $\beta$-carotene into vitamin $\mathrm{A}$. Goat milk fat contains more than 20 volatile branched-chain FA, including 4-methiloctanoic and 4-ethyloctanoic acid, which contribute to mutton-type and goat-type flavor, respectively (Sheehan et al., 2009). It is poor in casein; casein micelles contain more calcium, inorganic phosphorus, and non-centrifugal caseins, they are less solvated, less heat stable, and lose $\beta$-CN more quickly than cow milk casein micelles (Park et al., 2007). Renneting time for goat milk is shorter than for cow milk, and the weak consistency of the gel explains the low cheese yield.

The production of pasta filata cheeses using a mixture of ewe or goat milk could be an interesting and feasible opportunity for the dairy industry of Southern Italy, allowing its expansion in the market. Regarding this opportunity, the development of appropriate technologies for the production of innovative and reformulated cheeses, aimed at obtaining products with proper characteristics and satisfactory acceptance by consumers, is of particular interest. The goal of this study was to develop innovative Caciocavallo cheeses made from a mixture of ewe or goat milk with cow milk. The achieved cheeses were assessed for their physicochemical, microbiological, and sensorial characteristics through a comparison with traditional Caciocavallo cheeses made from cow milk.

\section{MATERIALS AND METHODS}

\section{Cheese Manufacture}

Raw cow, ewe, and goat milk were obtained from local dairy farmers. Cheeses were manufactured on an industrial scale in a local dairy industry (Caseificio Molisano L. Barone s.n.c., Vinchiaturo, Campobasso, Italy).

For each cheese, 3 productions were made: mixed cow/ewe milk (82:18, vol/vol; CE), mixed cow/goat milk (65:35, vol/vol; CG), and control cheeses made from cow milk (CC). Raw milk was pumped into a vat at $32^{\circ} \mathrm{C}$, in various quantities to achieve the desired proportion of cow and ewe or goat milk. Milks were inoculated with a commercial starter mix $(1 \mathrm{U} / 100 \mathrm{~L})$, composed of Streptococcus thermophilus, Lactococcus lactis ssp. lactis and ssp. cremoris, Lactobacillus helveticus, Lactobacillus casei, and Lactobacillus delbrueckii ssp. bulgaricus (Clerici-Sacco Group, Cadorago, Italy). Fermentation was carried out for approximately 40 min at 37 to $38^{\circ} \mathrm{C}$ and then commercial liquid calf rennet (Clerici-Sacco Group; $50 \mathrm{~mL} / 100 \mathrm{~L}$ for mixed ewe milk and $30 \mathrm{~mL} / 100 \mathrm{~L}$ for mixed goat milk) was added. When the curd reached the proper consistency (30-40 min), the cutting process started. The curd was cut into corn-size pieces; then, $60 \%$ of the whey was removed and maturation took place under whey. Before this last step, the curds of Caciocavallo cheeses made of $\mathrm{CG}$ milk were also cooked at $40^{\circ} \mathrm{C}$ for $35 \mathrm{~min}$. Afterward, the curd was put on a table where it was left to ripen until the $\mathrm{pH}$ reached a value of about 4.9 to 5.0 for CE and CG milk cheeses or higher (5.2-5.4) for $\mathrm{CC}$ milk cheeses. Then, curds were cut and mechanically stretched in hot water $\left(80^{\circ} \mathrm{C}\right)$ to produce cheeses of about $2 \mathrm{~kg}$. After shaping, cheeses were cooled in water at $4^{\circ} \mathrm{C}$ and then soaked in brine $(26 \% \mathrm{NaCl})$ for about $8 \mathrm{~h}$. Cheeses were ripened at $10^{\circ} \mathrm{C}$ and $80 \%$ relative humidity for $2 \mathrm{mo}$. Analyses were carried out on all samples on d 0 and during ripening at d 30 and 60 .

\section{Chemical and Physical Analysis}

Two cheeses from each production at each ripening time were sampled. All samples were analyzed in triplicate. Cheese samples were analyzed for fat (AOAC International, 2000; method 933.05), protein (AOAC International, 2000; method 920.123), moisture (AOAC International, 2000; method 948.12), ash (AOAC International, 2000; method 935.42), and lactose and galactose (Megazyme Kit K-LACGAR 02/05; Megazyme International Ireland, Bray, Co. Wicklow, Ireland). For $\mathrm{pH}$ measurement, the grated cheese samples $(10 \mathrm{~g})$ were mixed with equal quantities of distilled water $(10 \mathrm{~mL})$ 
and the $\mathrm{pH}$ of dispersion was measured using a Crison 2001 series pH meter (Crison Instruments SA, Barcelona, Spain). Titratable acidity (AOAC International, 2000; method 920.124) and color (Minolta Chroma Meter CR-200; Konica Minolta Business Solutions Italia S.p.a., Naples, Italy) in the CIELAB color space $\left(L^{*}, a^{*}, b^{*}\right)$, where $L^{*}$ represents lightness $\left(L^{*}=0\right.$ yields black and $\mathrm{L}^{*}=100$ indicates diffuse white), $\mathrm{a}^{*}$ is the position between red/magenta and green (negative values indicate green and positive values indicate magenta), and $b^{*}$ is the position between yellow and blue (negative values indicate blue and positive values indicate yellow) were also determined.

\section{Proteolysis}

Proteolysis was assessed by determining water-soluble nitrogen (SN) and NPN content. The amount of NPN, expressed as a percentage of total nitrogen $(\mathbf{T N}$; NPN/TN\%), and SN/TN\% were determined because they represent parameters to indicate the extent of proteolysis. For SN, $4 \mathrm{~g}$ of grated cheese was mixed with $20 \mathrm{~mL}$ of $\mathrm{H}_{2} \mathrm{O}$ at $40^{\circ} \mathrm{C}$ for $3 \mathrm{~min}$. The homogenate was adjusted to a final volume of $100 \mathrm{~mL}$ and was left at $4^{\circ} \mathrm{C}$ for $12 \mathrm{~h}$. Finally, it was filtered through Whatman no. 4 filter paper. For NPN, $10 \mathrm{~g}$ of grated cheese was mixed with $60 \mathrm{~mL}$ of $\mathrm{H}_{2} \mathrm{O}$ and $40 \mathrm{~mL}$ of $0.5 M$ sodium citrate. The homogenate was adjusted to a final volume of $200 \mathrm{~mL}$. Ten milliliters of this solution was adjusted to a final volume of $50 \mathrm{~mL}$ with $15 \%$ TCA. Finally, it was filtered through Whatman no. 5 filter paper. The nitrogen contents of the filtrates and the TN were determined by the Kjeldahl method (AOAC International, 2000; method 920.123).

\section{Lipolysis}

Lipolysis was expressed as acid degree value (ADV; APHA, 1985).

\section{Microbiological Analysis}

Microbiological analysis was carried out according to Di Criscio et al. (2010) and Panfili et al. (2008). Briefly, $10 \mathrm{~g}$ of each cheese was aseptically transferred into a sterile stomacher bag, diluted with $90 \mathrm{~mL}$ of sterile physiological solution (9 $\mathrm{g}$ of $\mathrm{NaCl} / \mathrm{L}$ ) and homogenized for $2 \mathrm{~min}$ in a Stomacher 400 laboratory blender (Seward Ltd., London, UK). Further decimal dilutions were carried out in sterile $0.1 \%$ (wt/vol) bacteriological peptone (Oxoid Ltd., Basingstoke, UK) and used for microbial counts. Total mesophilic bacteria counts were estimated on plate count agar (Oxoid Ltd.) after $48 \mathrm{~h}$ of incubation at $28^{\circ} \mathrm{C}$. Lactic acid bacteria (LAB) were counted, under anaerobiosis (AnaeroGen; Oxoid Ltd.), on de Man, Rogosa, and Sharpe (MRS) agar (Oxoid Ltd.) after $72 \mathrm{~h}$ of incubation at $22^{\circ} \mathrm{C}$ for mesophilic bacteria and $44^{\circ} \mathrm{C}$ for thermophilic bacteria. Thermophilic and mesophilic lactic acid cocci were counted on M17 agar (Oxoid Ltd.) after incubation for $72 \mathrm{~h}$ at 45 and $22^{\circ} \mathrm{C}$, respectively. Enterococci were counted on Slanetz and Bartley medium (Oxoid Ltd.) after incubation for $48 \mathrm{~h}$ at $37^{\circ} \mathrm{C}$. Enterobacteriaceae were estimated on VRBA (Oxoid Ltd.) after $36 \mathrm{~h}$ at $37^{\circ} \mathrm{C}$. Total and fecal coliforms were counted on violet red bile lactose agar (Oxoid Ltd.) after 24 to $48 \mathrm{~h}$ of incubation at 37 and $44^{\circ} \mathrm{C}$, respectively. Yeasts and molds were quantified on the surface of the cheese on yeast extract-peptone-dextrose medium (Reale et al., 2011) after $72 \mathrm{~h}$ of incubation at $25^{\circ} \mathrm{C}$.

\section{Sensorial Analysis}

The Caciocavallo samples aged for $30 \mathrm{~d}$ underwent sensory analysis. Each sample was evaluated 3 times. Samples were evaluated by a panel composed of 12 trained components. Sensory evaluation was carried out according to the Etana method described by Bozzetti et al. (2004) and modified by Chiavari et al. (2006). Cheese samples (1.5-cm height, 5.0-8.0-cm length, and $1.5-\mathrm{cm}$ depth) were coded with 3 -digit randomized numbers and served in a random order at room temperature (Zannoni et al., 2001).

The evaluated attributes were flavor and aroma: sweet, salty, bitter, and acidic. The tactile sensations as astringent, spicy, elasticity, hardness, friability, adhesiveness, solubility, and humidity were also evaluated. The precise definitions of each attribute are reported in Table 1 . The intensity of each attribute was rated on an increasing scale from 1 to 6 .

\section{Statistical Analysis}

An ANOVA was applied to the data. Least significant differences were obtained using a least significant difference test $(P<0.05)$. The scores from the descriptive sensory analysis were used to construct a principal components analysis (PCA) biplot. Statistical analysis was performed using SPSS for Windows software (version 13.0; SPSS Inc., Chicago, IL).

\section{RESULTS AND DISCUSSION}

\section{Experimental Design for the Cheese-Making Process}

The stretching procedure used to make pasta filata cheeses from ewe and goat milk, even mixed with cow milk, is difficult due to the poor cheese-making ability 
Table 1. Descriptive attributes and definitions used to evaluate Caciocavallo cheeses

\begin{tabular}{ll}
\hline Descriptor & Definition $^{1}$ \\
\hline Acid & $\begin{array}{l}\text { Primary taste produced by diluted aqueous solutions of most acidic substances, such as citric acid, tartaric acid, and } \\
\text { lactic acid }\end{array}$ \\
Adhesiveness & The effort needed for the tongue to detach a product stuck to the palate and the teeth \\
Aroma intensity & Organoleptic attribute perceptible by the olfactory organ via the back of the nose when tasting \\
Astringent & The complex sensation accompanied by shrinking, drawing, or puckering of the skin or mucous surface in the mouth \\
Bitter & Primary taste produced by diluted aqueous solutions of various substances, such as quinine and caffeine \\
Elasticity & Ability of a substance to recover its initial shape and dimension after being submitted to pressure \\
Flavor intensity & Organoleptic attribute perceptible by the olfactory organ on sniffing certain volatile substances \\
Hardness & Resistance to a given deformation \\
Humidity & Perception of the degree of humidity in the cheese sample \\
Salty & Primary taste produced by aqueous solutions of various substances such as sodium chloride \\
Solubility & A sensation that emerges when the sample melts extremely fast in the saliva \\
Spicy & Sensation that manifests itself in the mouth by itching, which could even lead to pain (fine needles) \\
Sweet & Primary taste produced by aqueous solutions of various substances, such as sucrose or fructose \\
\hline 1Bozen &
\end{tabular}

${ }^{1}$ Bozzetti et al. (2004).

of these types of milk. Therefore, as few references are available in the literature, the study of an appropriate technology and processing parameters is important to produce products with proper characteristics and satisfactory acceptance.

The cheese-making process was carried out using the standard Caciocavallo cheese-making technology, introducing changes when appropriate. The different milk percentages, the required rennet amount and the time of coagulum, and the $\mathrm{pH}$ of the curd at the stretching point were selected on the basis of preliminary tests, depending on the coagulation ability of the obtained mixtures and on the stretching properties of the curd (data not shown). Each milk percentage varied within a relatively narrow range, compatible with a reasonable quality standard of the final product, mainly with respect to the DM content. The optimal final ratios were the following: $82: 18$ (vol/vol) for $\mathrm{CE}$ milk and 65:35 (vol/vol) for CG milk. The $\mathrm{pH}$ values for CE and CG milk cheeses were chosen to confer the optimum stretch ability to the curds: higher $\mathrm{pH}$ values gave a tough curd that fractured during stretching, whereas lower $\mathrm{pH}$ values resulted in a soft curd that collapsed during stretching. Moreover, before the cutting step, the curds of Caciocavallo cheeses made of CG milk were also cooked at $40^{\circ} \mathrm{C}$ for $35 \mathrm{~min}$, with the aim of accelerating curd draining (Imm et al., 2003; Alichanidis and Polychroniadou, 2008). The cheese-making technology used in the experiments is summarized in Figure 1. The exact details of the cheese-making technology are reported in the Materials and Methods section.

\section{Chemical and Physical Analyses of the Different Cheeses}

During ripening, all Caciocavallo samples showed a slight $\mathrm{pH}$ decrease and a consequent increase in acidity values. The percentage of added milk, even if relatively low, caused changes in the compositional and nutritional characteristics of the innovative products (Table 2 ). The composition of milk was $3.6 \%$ protein, $4.4 \%$ fat, and $4.0 \%$ lactose for CC milk; $4.0 \%$ protein, $4.6 \%$ fat, and $4.3 \%$ lactose for CE milk; and $3.5 \%$ protein, $4.1 \%$ fat, and $4.3 \%$ lactose for CG milk. After production and during ripening, the $\mathrm{CG}$ sample had a significantly lower fat content and higher ash content than the CC sample. The lower fat content may be associated with the different composition of the initial mixed milk and with a higher fat loss in the hot water used to stretch the curd, caused by the smaller fat globules in goat milk. The different added milks had no significant effect on cheese proteins. Lactose and galactose showed different values among samples, because of different microbial activities and, at d 60 of ripening, they were absent in all samples. In all samples, the change in color $\left(\mathrm{L}^{*}, \mathrm{a}^{*}, \mathrm{~b}^{*}\right)$, monitored on the surface and in the inner part of cheeses, did not show significant changes (Table $2)$.

Significant differences in proteolysis were observed among the different cheeses. The value of $\mathrm{SN} / \mathrm{TN} \%$ increased during ripening, reaching, at d 60, similar values for CC and CE cheeses (14.8 and 14.6\%, respectively), whereas it was higher for CG cheese $(31.2 \%)$. The percentage ratio between $\mathrm{SN}$ fractions and $\mathrm{TN}$ is an index of the rate and extent of proteolysis; it is an indicator of casein hydrolysis caused by the action of rennet and milk proteases present at the beginning of ripening. This water-soluble fraction is very heterogeneous in terms of composition, and includes whey proteins and high-, medium-, and low-molecular weight peptides as well as amino acids. It should be mentioned that a significant part of SN (25 to $30 \%$ of the SN of mature cheese) is produced during curd acidification and, consequently, it is partly lost into the water or 


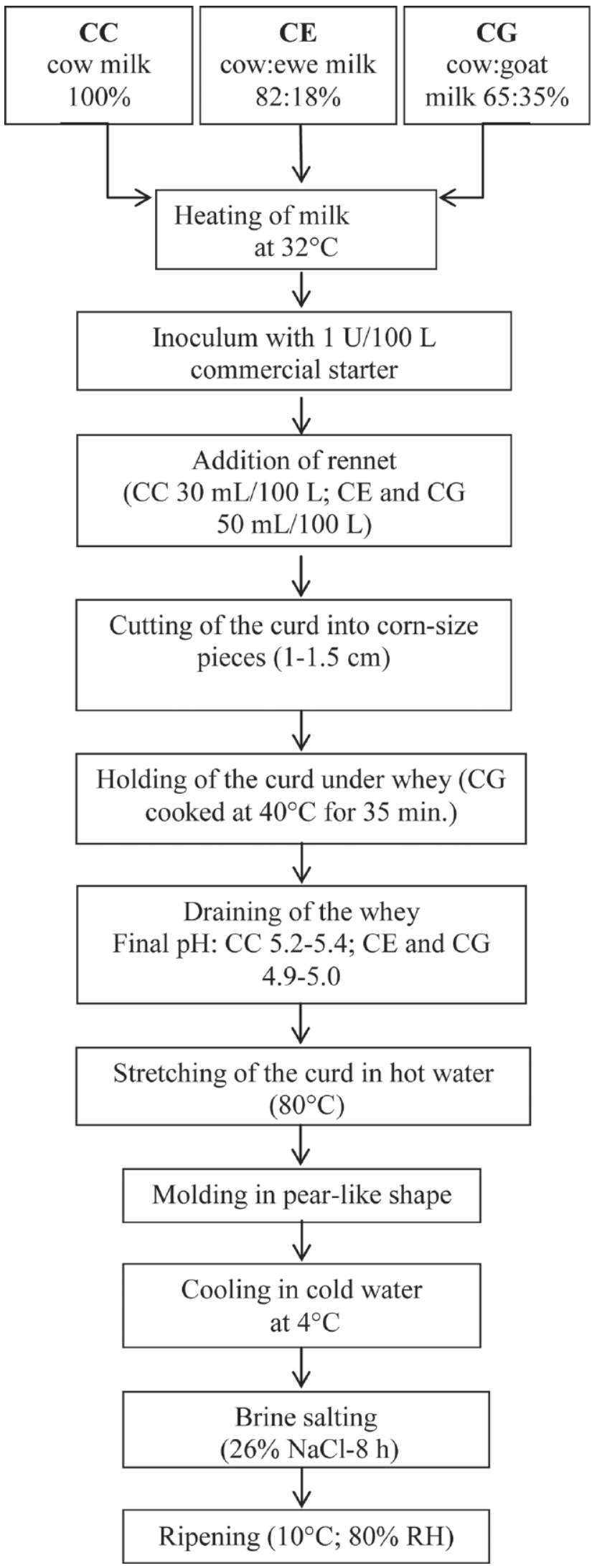

Figure 1. Protocol for the production of Caciocavallo cheeses. brine during the texturization process (Alichanidis and Polychroniadou, 2008). Our data are partially confirmed by the work of Molina et al. (1999), where the cheeses made from goat milk showed the highest concentrations of SN/TN\% compared with those made solely from cow milk. The NPN/TN\% index increased during and at the end of ripening, reaching values of 11.8, 9.2, and $7.5 \%$ for $\mathrm{CC}, \mathrm{CE}$, and $\mathrm{CG}$ cheeses, respectively. This index expresses the amount of low-molecular-mass peptides and amino acids, which are soluble in $12 \%$ TCA, formed from the breaking-off of casein and high- and medium-molecular-mass peptides by microorganisms and rennet. Therefore, the amount of NPN/TN\% increases with the age of cheeses. The different behavior found is an index of slower proteolysis in CG cheese $(P$ $<0.05)$ and faster proteolysis in $\mathrm{CC}$ and $\mathrm{CE}$ cheeses $(P<0.05)$. These results are confirmed by the work of Imm et al. (2003), which compared proteolysis in cow and goat Mozzarella cheeses during storage.

A measure of lipolysis is represented by the determination of ADV. This value is a measure of the content of FFA dissolved in a certain amount of fat and it can be correlated to the sensorial quality of the finished products (Deeth and Fitz-Gerald, 1976). Figure 2 shows the lipolysis evolution expressed as percentage increment of ADV during ripening. The CE and CG cheeses showed evident lipolysis phenomena at d 30; instead, CC cheese showed lower values of ADV. At d 60, lipolysis of CC cheese increased, but it remained lower than that of $\mathrm{CE}$ and $\mathrm{CG}$ cheeses. Lipolytic action mainly depends on lipase activity. Short-chain FA are in position sn3 of triacylglycerols, which is more susceptible to lipase action; therefore, the higher levels of short-chain FA in goat cheeses are likely to have greater lipolytic effects than their cow cheese counterparts (Park, 2001; Park et al., 2007).

\section{Microbiological Analyses of the Different Cheeses}

The microbiological data related to produced Caciocavallo cheeses showed a prevalence of lactic acid bacteria, in accordance with previous studies (Coppola et al., 2003). Mesophilic and thermophilic LAB, in cocci and rod forms, showed high counts already at the beginning of production (Figure 3). In particular, mesophilic forms, from an initial value of $5 \mathrm{log} \mathrm{cfu} / \mathrm{g}(\mathrm{CC})$ and 6 $\log \mathrm{cfu} / \mathrm{g}(\mathrm{CE}$ and $\mathrm{CG}$ ), showed an increasing trend during ripening, reaching values of about $7 \log \mathrm{cfu} / \mathrm{g}$, in contrast to thermophilic forms that showed a decreasing trend. In fact, the mesophilic LAB took advantage over the thermophilic LAB due to the low ripening temperatures. Significant differences were found among samples from different productions. In particular, samples made from mixed milks resulted in higher counts of meso- 


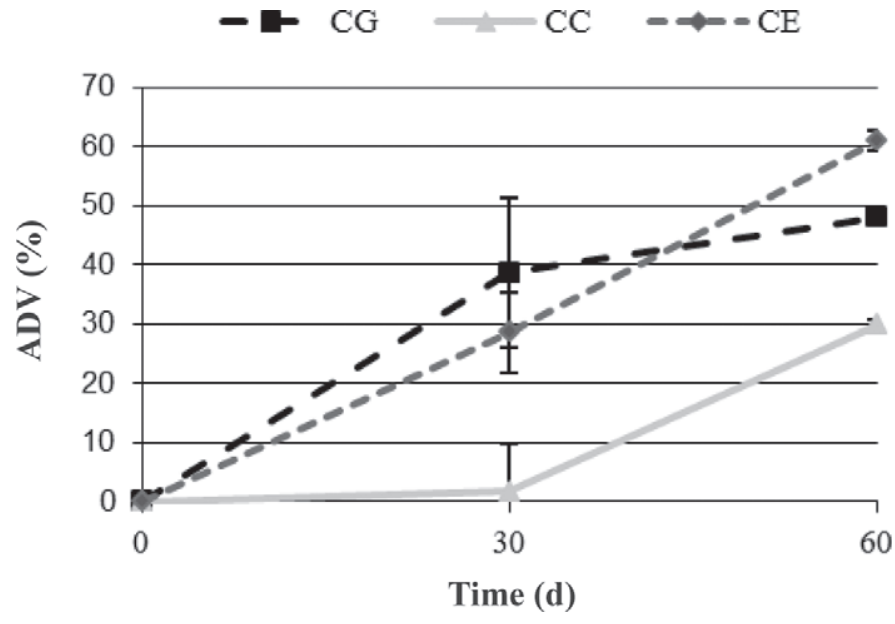

Figure 2. Lipolysis in Caciocavallo cheeses during ripening. $\mathrm{CC}=$ cow Caciocavallo cheese (control); $\mathrm{CE}=$ mixed cow/ewe Caciocavallo cheese; $\mathrm{CG}=$ mixed cow/goat Caciocavallo cheese: $\mathrm{ADV}=$ acid degree value. Error bars indicate standard deviations.

philic LAB than the controls. As already reported by several authors, mesophilic bacteria do not come from the starter only, but their origin is also attributed to raw milk (Coppola et al., 2003; Mucchetti and Neviani, 2006). Therefore, ewe and goat milk could be higher sources of lactic mesophilic forms than cow milk. In contrast, control cheeses highlighted a higher presence of thermophilic LAB. The observed different proteolysis could depend on the different microbiota (Piraino et al., 2008). In all samples, total mesophilic bacteria showed a trend very similar to that registered for mesophilic LAB, whereas enterococci showed a trend close to that of thermophilic LAB (data not shown). At $60 \mathrm{~d}$ of ripening, the fecal coliforms were undetectable in all samples. The other undesirable microorganisms, such as molds, enterobacteria, and total coliforms, were found at very low levels or were undetectable in all samples (data not shown).

\section{Sensory Characteristics}

The sensory analysis was carried out at $30 \mathrm{~d}$ of ripening (Figure 4). Results showed that scores found for tactile sensations and some taste features were significantly different $(P<0.05)$.

To better visualize any differences among cheeses from different milks, with respect to microbiological characteristics and sensorial attributes, the scores from descriptive sensorial analysis were used to construct a PCA biplot (Figure 5). The PCA resulted in 2 principal components that accounted for about $95 \%$ of the total variance. Mixed ewe cheeses $(\mathrm{CE})$ were located in a well-defined area where cheeses displayed higher scores for intensity of flavor, acidic, astringent, friability and salty attributes. Hardness increased, in accordance with what was found by Aminifar et al. (2013). In contrast, mixed goat cheeses (CG) were found in an area where the solubility, together with the intensity

Table 2. Composition of the different Caciocavallo cheeses at 0,30 , and $60 \mathrm{~d}$ of ripening

\begin{tabular}{|c|c|c|c|c|c|c|c|c|c|}
\hline \multirow{2}{*}{ Item $^{1}$} & \multicolumn{9}{|c|}{ Caciocavallo cheese $^{2}$} \\
\hline & \multicolumn{3}{|c|}{$\mathrm{CC}$} & \multicolumn{3}{|c|}{$\mathrm{CE}$} & \multicolumn{3}{|c|}{$\mathrm{CG}$} \\
\hline $\mathrm{pH}$ & $5.56^{\mathrm{a}}$ & $5.51^{\mathrm{b}}$ & $5.48^{\mathrm{b}}$ & $5.57^{\mathrm{a}}$ & $5.39^{\mathrm{c}}$ & $5.36^{\mathrm{c}}$ & $5.72^{\mathrm{d}}$ & $5.59^{\mathrm{a}}$ & $5.62^{\mathrm{a}}$ \\
\hline Acidity ( $\mathrm{g} / 100 \mathrm{~g}$ of lactic acid) & $0.19^{\mathrm{a}}$ & $0.25^{\mathrm{b}}$ & $0.32^{\mathrm{c}}$ & $0.20^{\mathrm{a}}$ & $0.29^{\mathrm{c}}$ & $0.36^{\mathrm{c}}$ & $0.21^{\mathrm{a}}$ & $0.23^{\mathrm{a}}$ & $0.38^{\mathrm{c}}$ \\
\hline Moisture (\%) & $46.0^{\mathrm{a}}$ & $41.5^{\mathrm{b}}$ & $39.9^{\mathrm{c}}$ & $45.4^{\mathrm{a}}$ & $41.9^{\mathrm{b}}$ & $39.8^{\mathrm{c}}$ & $44.9^{\mathrm{a}}$ & $42.1^{\mathrm{b}}$ & $41.4^{\mathrm{c}}$ \\
\hline $\operatorname{Ash}(g / 100 \mathrm{~g}$ of $\mathrm{DM})$ & $6.22^{\mathrm{a}}$ & $6.10^{\mathrm{a}}$ & $6.74^{\mathrm{a}}$ & $6.87^{\mathrm{a}}$ & $7.17^{\mathrm{a}}$ & $7.36^{\mathrm{a}}$ & $8.14^{\mathrm{b}}$ & $8.22^{\mathrm{b}}$ & $8.10^{\mathrm{b}}$ \\
\hline Lactose $(\mathrm{g} / 100 \mathrm{~g}$ of DM) & $0.15^{\mathrm{a}}$ & $0.00^{\mathrm{b}}$ & $0.00^{\mathrm{b}}$ & $0.00^{\mathrm{b}}$ & $0.00^{\mathrm{b}}$ & $0.00^{\mathrm{b}}$ & $0.00^{\mathrm{b}}$ & $0.00^{\mathrm{b}}$ & $0.00^{\mathrm{b}}$ \\
\hline Galactose (g/100 g of DM) & $0.70^{\mathrm{a}}$ & $0.04^{\mathrm{b}}$ & $0.00^{\mathrm{c}}$ & $1.04^{\mathrm{d}}$ & $0.09^{\mathrm{b}}$ & $0.00^{\mathrm{c}}$ & $1.40^{\mathrm{d}}$ & $0.00^{\mathrm{c}}$ & $0.02^{\mathrm{c}}$ \\
\hline $\mathrm{SN} / \mathrm{TN}(\%)$ & $12.5^{\mathrm{a}}$ & $13.2^{\mathrm{b}}$ & $14.8^{\mathrm{c}}$ & $11.3^{\mathrm{d}}$ & $12.7^{\mathrm{a}}$ & $14.6^{\mathrm{c}}$ & $16.4^{\mathrm{e}}$ & $19.2^{\mathrm{f}}$ & $31.2^{\mathrm{g}}$ \\
\hline NPN/TN (\%) & $1.9^{\mathrm{a}}$ & $6.5^{\mathrm{b}}$ & $11.8^{\mathrm{c}}$ & $1.1^{\mathrm{d}}$ & $1.6^{\mathrm{a}}$ & $9.2^{\mathrm{c}}$ & $3.6^{\mathrm{e}}$ & $6.1^{\mathrm{f}}$ & $7.5^{\mathrm{g}}$ \\
\hline $\mathrm{L}^{*}$ of surface & $91.5^{\mathrm{a}}$ & $67.4^{\mathrm{b}}$ & $66.8^{\mathrm{b}}$ & $91.7^{\mathrm{a}}$ & $67.2^{\mathrm{b}}$ & $66.9^{\mathrm{b}}$ & $91.7^{\mathrm{a}}$ & $66.9^{\mathrm{b}}$ & $67.2^{\mathrm{b}}$ \\
\hline $\mathrm{a}^{*}$ of surface & $-6.3^{\mathrm{a}}$ & $-8.0^{\mathrm{b}}$ & $-7.8^{\mathrm{b}}$ & $-6.3^{\mathrm{a}}$ & $-8.5^{\mathrm{b}}$ & $-8.8^{\mathrm{b}}$ & $-6.5^{\mathrm{a}}$ & $-8.4^{\mathrm{b}}$ & $-8.6^{\mathrm{b}}$ \\
\hline
\end{tabular}



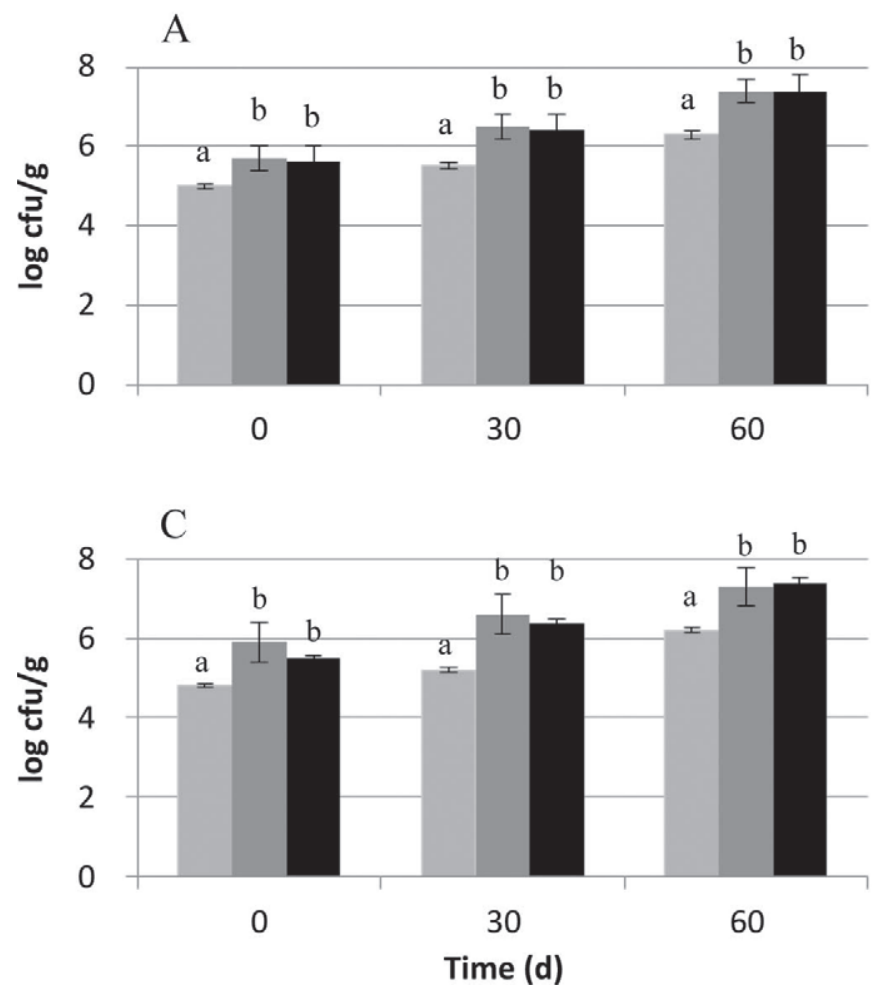

B

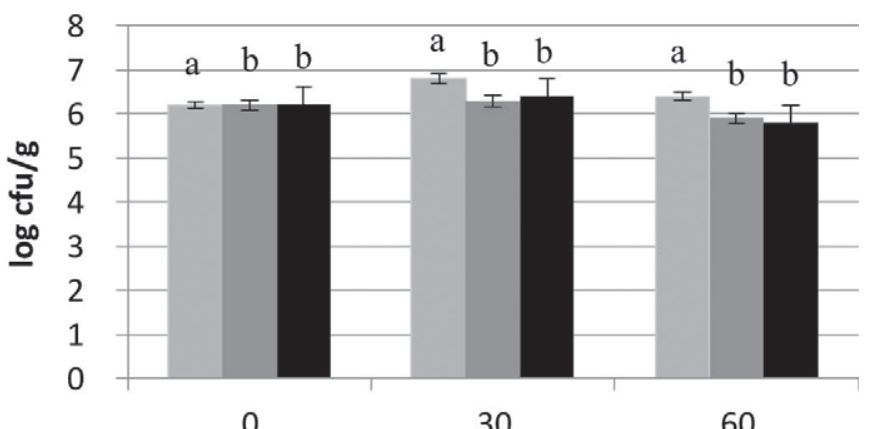

$\mathrm{D}$

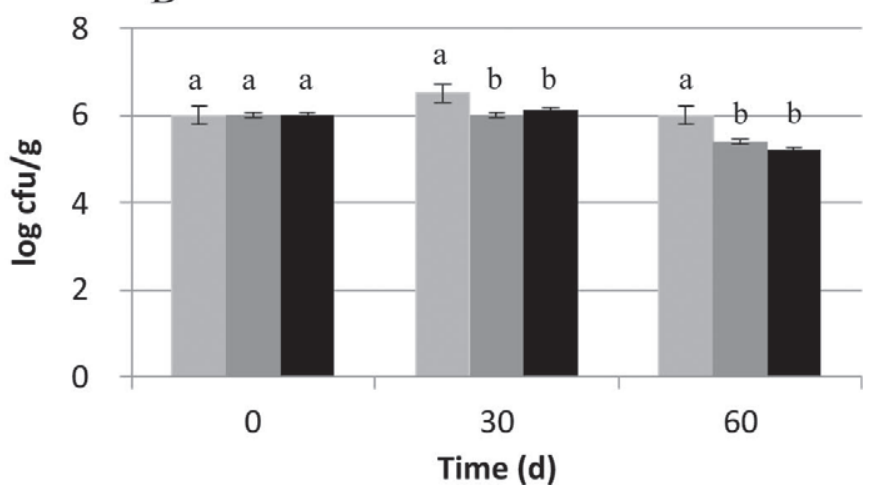

Figure 3. Mesophilic (A) and thermophilic (B) cocci lactic acid bacteria (LAB), and mesophilic (C) and thermophilic (D) rod LAB during ripening. $\mathrm{CC}=$ cow Caciocavallo cheese (control); $\mathrm{CE}=$ mixed cow/ewe Caciocavallo cheese; $\mathrm{CG}=$ mixed cow/goat Caciocavallo cheese. Different letters $(\mathrm{a}$ and $\mathrm{b})$ at the same ripening time indicate significant differences $(P<0.05)$. Error bars indicate standard deviations.

of the aroma and bitter attributes, were predominant. Cow cheeses (CC) were characterized by higher scores regarding sweet attributes and elasticity, adhesiveness, and humidity. Regarding the microbiota, the PCA confirmed the different distribution of mesophilic and thermophilic LAB among the cheeses produced. The above-reported results showed that ewe and goat milk, added to cow milk during cheese making, substantially influenced the structure of the produced cheese. The low scores of the CG sample for the intensity of flavor were confirmed by the lower proteolytic activity, as also observed by Yvon and Rijnen (2001). Moreover, cheeses with evident lipolysis, as observed for mixed products, differ for strong flavors (Kindstedt et al., 2004). The data also confirmed the influence of the starting milk, as the peculiar flavor and texture, typical of ewe and goat milk cheeses, could be partly explained by compositional differences in caseins and fats with respect to cow milk. The influence of milk composition on cheese structure has been reported by Pereira et al. (2011). In addition, in raw milk cheeses, the native microbiota may have played an important role and have contributed to their distinct sensorial characteristics.

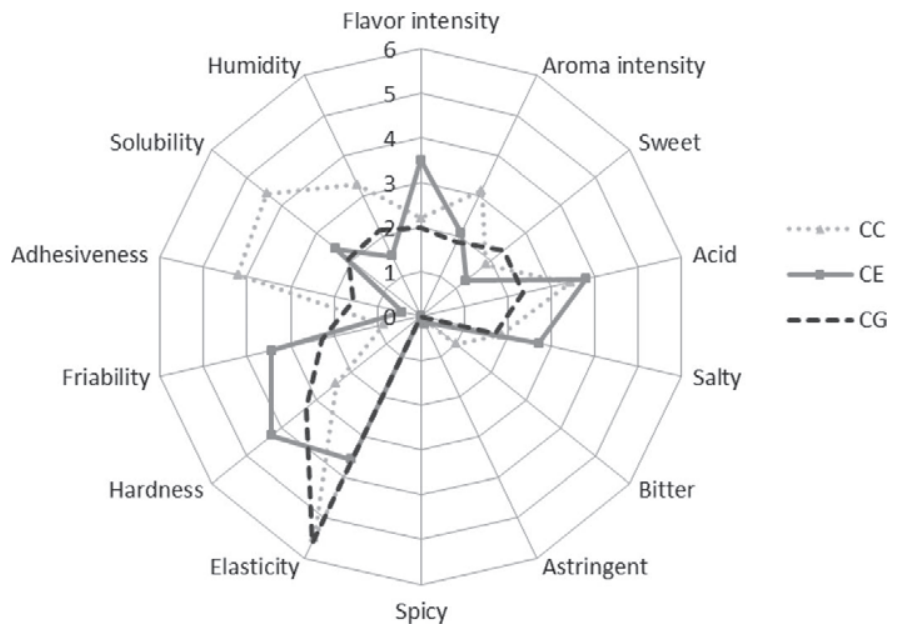

Figure 4. Sensorial profile of the realized Caciocavallo cheeses. $\mathrm{CC}=$ cow Caciocavallo cheese (control); $\mathrm{CE}=\operatorname{mixed}$ cow $/$ ewe Caciocavallo cheese; $\mathrm{CG}=$ mixed cow/goat Caciocavallo cheese. The intensity of each attribute was rated on an increasing scale from 1 to 6 . 


\section{biplot}

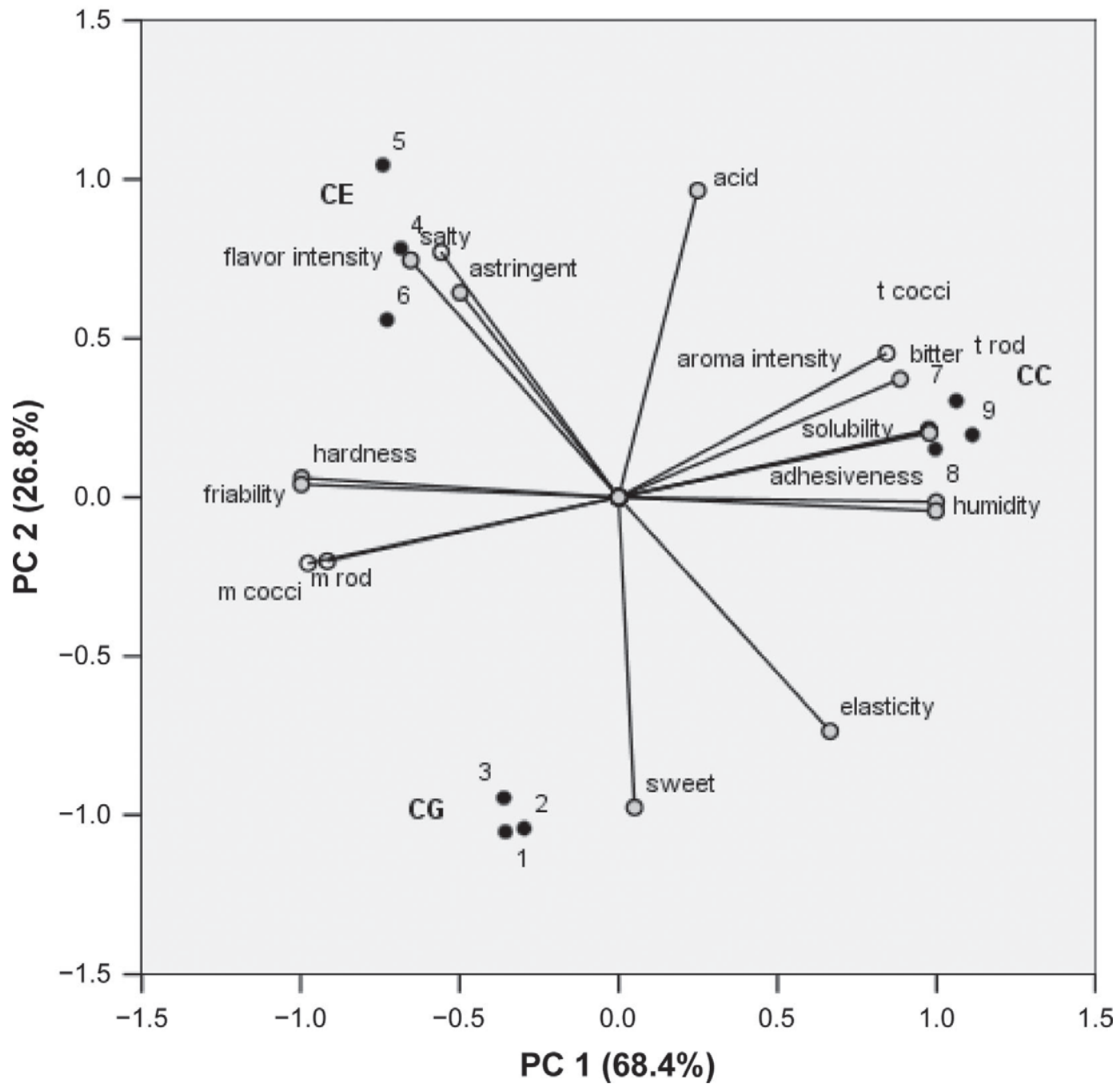

Figure 5. Principal components (PC) analysis of sensorial attributes and microbial characteristics of the realized Caciocavallo cheeses. CC $=$ cow Caciocavallo cheese $(7,8$, and 9 ; control); $\mathrm{CE}=$ mixed cow/ewe Caciocavallo cheese $(4,5$, and 6$)$; CG $=$ mixed cow/goat Caciocavallo cheese $(1,2$, and 3$) ; \mathrm{t}=$ thermophilic; $\mathrm{m}=$ mesophilic.

\section{CONCLUSIONS}

Partial substitution of cow milk with ewe or goat milk in pasta filata cheese production had an effect on physicochemical, microbiological, and sensorial characteristics of the final products. The different compositions of raw milk contributed to the peculiar sensorial attributes of the innovative produced cheeses, also influenced by the native microbiota of the different milks. All innovative and traditional Caciocavallo cheeses showed a satisfactory nutritional, sensorial, and microbiological quality. Moreover, considering the peculiar nutritional properties of goat milk, the realized mixed goat Caciocavallo cheeses could lead to good success among consumers interested in healthy foods.
The development of appropriate technologies for the production of innovative cheeses using a mixture of cow and ewe or goat milk, with proper characteristics and satisfactory acceptance by consumers, could be an interesting and feasible opportunity for the dairy industry, allowing its expansion in the market. In addition, considering the almost total absence of scientific papers on these types of pasta filata cheeses, the obtained results could give more insight into the characterization of these products.

\section{ACKNOWLEDGMENTS}

The authors thank Caseificio Molisano L. Barone s.n.c. (Vinchiaturo, Campobasso,, Italy) for the realiza- 
tion of the cheeses. This study was financially supported by Programma Operativo Regionale (POR) Molise 2000/06: PROGETTO RE007 (Molise, Italy) for the project "Sicurezza alimentare e innovazione tecnologica dei prodotti caseari freschi a pasta filata."

\section{REFERENCES}

Albenzio, M., A. Santillo, M. Caroprese, A. Braghieri, A. Sevi, and F. Napolitano. 2013. Composition and sensory profiling of probiotic Scamorza ewe milk cheese. J. Dairy Sci. 96:2792-2800.

Alichanidis, E., and A. Polychroniadou. 2008. Characteristics of major traditional regional cheese varieties of East-Mediterranean countries: A review. Dairy Sci. Technol. 88:495-510.

Aminifar, M., M. Hamedi, Z. Emam-Djomeh, and A. Mehdinia. 2013. The effect of ovine and bovine milk on the textural proprieties of Lighvan cheese during ripening. Int. J. Dairy Technol. 66:45-53.

AOAC International. 2000. Official Methods of Analysis. Vol. 2. 17th ed. AOAC International, Gaithersburg, MD.

APHA (American Public Health Association). 1985. Standard Methods for the Examination of Dairy Products. 15th ed. APHA, Washington, DC.

Bozzetti, V., B. Morara, and M. Zannoni. 2004. ETANA: Un modello per definire il profilo organolettico di tutti i formaggi. Il Latte 11:66-69.

Chiavari, C., M. Nanni, G. Ferri, B. Morara, and G. Qualizza. 2006 Formare assaggiatori per la valutazione sensoriale della Mozzarella di bufala. Il Latte 11:66-70.

Coppola, R., M. Succi, E. Sorrentino, M. Iorizzo, and L. Grazia. 2003. Survey of lactic acid bacteria during the ripening of Caciocavallo cheese produced in Molise. Lait 83:211-222.

Deeth, H. C., and C. H. Fitz-Gerald. 1976. Lipolysis in dairy products: A review. Aust. J. Dairy Technol. 31:53-64.

Di Criscio, T., A. Fratianni, R. Mignogna, L. Cinquanta, R. Coppola, E. Sorrentino, and G. Panfili. 2010. Production of functional probiotic, prebiotic, and synbiotic ice creams. J. Dairy Sci. 93:45554564 .

Hussain, I., A. E. Bell, and A. S. Grandison. 2011. Comparison of the rheology of Mozzarella-type curd made from buffalo and cows' milk. Food Chem. 128:500-504.

Imm, J. Y., E. J. Oh, K. S. Han, S. Oh, Y. W. Park, and S. H. Kim. 2003. Functionality and physic-chemical characteristics of bovine and caprine Mozzarella cheeses during refrigerated storage. J. Dairy Sci. 86:2790-2798.

Kindstedt, P., M. Carić, and S. Milanivić. 2004. Pasta filata cheeses. Pages 251-277 in Cheese Chemistry, Physics and Microbiology. Vol. 1. 3rd ed. P. F. Fox, P. L. H. McSweeney, T. M. Cogan, and T. P. Guinee, ed. Elsevier Academic Press, London, UK.

Litopoulou-Tzanetaki, E., and N. Tzanetakis. 2011. Microbiological characteristics of Greek traditional cheeses. Small Rumin. Res. 101:17-32.
Moatsou, G., K. Ioannis, E. Moschopoulou, E. Anifantakis, and E. Alichanidis. 2001. Effect of technological parameters on the characteristics of kasseri cheese made from raw or pasteurized ewes' milk. Int. J. Dairy Technol. 54:69-77.

Molina, E., M. Ramos, L. Alonso, and R. López-Fandiño. 1999. Contribution of low molecular weight water soluble compounds to the taste of cheese made of cows', ewes' and goats' milk. Int. Dairy J. 9:613-621.

Mucchetti, G., B. Bonvini, M. C. Remagni, R. Ghiglietti, F. Locci, S. Barzaghi, S. Francolino, A. Perrone, A. Rubiloni, P. Campo, M. Gatti, and D. Carminati. 2008. Influence of cheese-making technology on composition and microbiological characteristics of Vastedda cheese. Food Contr. 19:119-125.

Mucchetti, G., and E. Neviani. 2006. Microbiologia e tecnologia lattiero casearia. Qualità e sicurezza. Tecniche Nuove SpA, MI, Italy.

Niro, S., A. Fratianni, R. Mignogna, P. Tremonte, E. Sorrentino, and G. Panfili. 2012. An innovative pre-ripening drying method to improve the quality of pasta filata cheeses. J. Dairy Res. 79:397-404.

Panfili, G., A. Fratianni, T. Di Criscio, D. Gammariello, and E. Sorrentino. 2008. Influence of microorganisms on retinol isomerization in milk. J. Dairy Res. 75:37-43.

Park, Y. W. 2000. Comparison of mineral and cholesterol composition of different commercial goat milk products manufactured in USA. Small Rumin. Res. 37:115-124.

Park, Y.W. 2001. Proteolysis and lipolysis of goat milk cheese. J. Dairy Sci. 84(E. Suppl.):E84-E92.

Park, Y. W., M. Juárez, M. Ramos, and G. F. W. Haenlein. 2007. Physico-chemical characteristics of goat and sheep milk. Small Rumin. Res. 68:88-113.

Pereira, C. I., M. I. Franco, A. M. P. Gomes, and F. X. Malcata. 2011. Microbiological, rheological and sensory characterization of Portuguese model cheeses manufactured from several milk sources. Lebensm. Wiss. Technol. 44:2244-2252.

Piraino, P., T. Zotta, A. Ricciardi, P. L. H. McSweeney, and E. Parente. 2008. Acid production, proteolysis, autolytic and inhibitory properties of lactic acid bacteria isolated from pasta filata cheeses: A multivariate screening study. Int. Dairy J. 18:81-92.

Reale, A., T. Di Renzo, M. Succi, P. Tremonte, R. Coppola, and E. Sorrentino. 2011. Identification of lactobacilli isolated in traditional ripe wheat sourdoughs by using molecular methods. World J. Microbiol. Biotechnol. 27:237-244.

Sheehan, J. J., A. D. Patel, M. A. Drake, and P. L. H. McSweeney. 2009. Effect of partial or total substitution of bovine for caprine milk on the compositional, volatile, non-volatile and sensory characteristics of semi-hard cheeses. Int. Dairy J. 19:498-509.

Yvon, M., and L. Rijnen. 2001. Cheese flavour formation by amino acid catabolism. Int. Dairy J. 11:185-201.

Zannoni, M., B. Morara, and L. Bertozzi. 2001. La degustazione dei formaggi. Guida all'analisi sensoriale. ANFOSC Ediservice, Potenza, Italy.

Zicarelli, L. 2004. Buffalo milk: Its properties, dairy yield and Mozzarella production. Vet. Res. Commun. 28:127-135. 